\title{
The Activities Undertaken by the Central Department of Geography, Tribhuvan University: 2010-2011
}

\author{
Pushkar K Pradhan, PhD \\ Professor and Head \\ Central Department of Geography, Tribhuvan University \\ pushkar@reachpuba.ora
}

\begin{abstract}
Introduction
The Central Department of Geography (CDG) at Kirtipur is one of the leading Departments of the Faculty of Humanities and Social Sciences, Tribhuvan University. The Department was established in 1958. Since then, it has been actively serving the country in higher education and research. CDG runs regular Master's programme in Geography. The PhD programme in Geography is run by the Faculty of Humanities and Social Sciences (FHSS). From the very beginning, the PhD programme in Geography was open to all disciplines related to or interested in Geography, but since the last year the FHSS has made it limiting to only those having Master's degree in Geography, breaking up the long established system adopted by the Geography Subject Committee. CDG is a pioneer Department in running courses such as Geographic Information Systems (GIS) and Remote Sensing (RS) in Nepal. Being a central department, it has to look after of the academic programmes and activities of 22 Departments of Geography under the Tribhuvan University's constituent campuses spreading across all corners of the country, where there is bachelor level programme in Geography. Of these, the Department of Geography at Prithvi Narayan Campus, Pokhara also runs regular Master's degree, in addition to bachelor level. This paper intends to portray the academic activities being undertaken by the CDG from 2010 to 2011 in regard to strengthening geography subject, based on the information recorded at the CDG.
\end{abstract}

\section{Publications}

The CDG has brought out the following academic publications:

- 2010. Environment, Livelihood and Micro Enterprises. Editors - Pushkar K Pradhan, Bhim P Subedi and Narendra R Khanal, published by the Central Department of Geography, Tribhuvan University.

- 2010. Geographic Base. Issue 2. The Annual Journal of the Nepal Geographical Student Society, Central Department of Geography, Tribhuvan University. 
- 2010-11. Geographical Journal of Nepal. Volume 8. Editors - Pushkar K Pradhan, Narendra R Khanal, and Hriday L Koirala. The publication of the Central Department of Geography, Tribhuvan University.

- 2011. Environmental Resources and Cultural Landscapes: Understanding Changing Spatial Organization of Bhimeshwor, Dolakha. Editor - Pushkar K Pradhan, published by the Central Department of Geography, Tribhuvan University.

- 2011. Geographical Base. Issue 3. The Annual Journal of the Nepal Geographical Student Society, Central Department of Geography, Tribhuvan University.

\section{Research Works}

In addition to run a regular Master's degree programme, CDG is carrying out or has completed the following research studies and projects. CDG has been awarded these studies through competition.

- 2010. CDG has successfully completed the research project "Natural Resources Based Micro Enterprise Projects of Rolpa District" for the GoN/UNDP supported Micro Enterprise Development Programme (MEDEP).

- 2011. CDG has been awarded the institution research project with Rs 1000,000 by the University Grants Commission (UGC). The research "Interbasins Transfer of Water and its Consequences: A Case Study of Kulekhani and Rapti Rivers" headed by Prof Narendra R Khanal will be completed in 2012.

- 2011. GIS analysis of land use and land use change of the Koshi Hills, as a part of "Research into Long Term Impact of Development Interventions in the Koshi Hills of Nepal" by GRM International Limited, London, UK for the DFID Nepal and India, coordinated and led by Ms Puspa Sharma will be completed by the end of 2012.

- 2011. Vulnerability Assessment of Meteorological Flash Floods in Poiqu/Bhotekoshi/Sunkoshi Watershed with the Asian International Rivers Center, Yunnan University, Kunming, Yunnan, China, ICIMOD and Climate Change Adaptation through Water Resource Management: Comparative Study between the Yellow and the Koshi River Basins, together with the Research Centre for IRBM, Peking University, Beijing, China and ICIMOD by the support of the World Bank. These joint research studies led by Prof Narendra R Khanal and coordinated by Dr Hriday L Koirala and Dr Pashupati Nepal will be completed in 2012.

\section{Joint Study and Visit Programmes}

To strengthen its academic activities and extend cooperation with partner universities and research centres, the CDG has completed the following joint study programmes successfully:

- April, 2010. Under the support programme of the Eurasia-Pacific Uninet, Salzburg, Austria, the CDG's faculty member - Mr Chhabi L Chidi and nine students (boys and girls) joined the study team, comprising other faculty members and students of the Central Department of Environment Science, TU, Nepal and two universities of Graz, Austria such as University of Technology and Karl Franzens University, as well as researchers of ICIMOD and the Himalayan Research Expedition, Nepal spent 10 days to study Rock Glacier Monitoring Technology Transfer between Eastern Alps and Eastern Himalayas in the Langtang valley and observed the physical (topography, fluvial, glacial, periglacial, and Yala glacial lake) and other aspects such as climate change impacts, tourism, nomadic communities in the Langtang 
region. Prior to this, a two-day workshop for the participants and others interested was held at the CDG by the specialists of the universities of Graz, Austria. Under the exchange programme, the CDG Head - Prof Dr Pushkar K Pradhan visited the Institute of Remote Sensing and Photogrammetry, Graz University of Technology, Austria and meanwhile also many other universities and institutes, including the University of Graz, Austria, Institute of Geography and Regional Studies, University of Klagenfurt, Austria, University of Primorska and University of Ljubljana, Slovenia, Comenius University (Bratislava), Slovakia, and Selye Janos University (Komárno) and Szent Istvan University (Gödöllö/Budapest), Hungary on invitation of the host universities during April-May.

- May- June 2011. Prof Pradhan visited on invitation to the University of Bergen and involved in writing joint research proposals to be applied to the Norwegian Council of Sciences and delivered a guest lecture on "Ecosystem Integrity Approach to Regional Development in Nepal".

- August-September 2011. CDG's two faculty members - Ms Puspa Sharma and Mr Sher B Gurung, together with many invitees from other organizations of Nepal - visited different parts across east-west of the USA to know about the 'Disaster and Crisis Management' under the International Visitors for Leadership Program (IVLP) organized and sponsored by the Public Affairs Section of the Embassy of the United States of America, Kathmandu, Nepal. They benefitted from knowing about various approaches, technologies such as GIS, and elements of crisis and disaster management by this program.

- Under the joint programmes, affiliating to the CDG, the Master's students from the Klagenfurt University, Austria, the University of Graz, Austria, 3 Masters and 1 PhD students from the Centre for Himalayan Studies, French National Centre for Scientific Research (Centre National de la Recherche Scientifique - CNRS, and a PhD student from Department of Land Use/Cover Change and Land Resources, LUCCR, IGSNRR, Chinese Academy of Sciences, Peking, China completed their field research works covering the Tarai districts, the Koshi basin, the Everest region and western hills.

\section{Training}

CDG has conducted the GIS/RS training on demand basis of the clienteles. The GIS/RS training has been conducted by the CDG since 1994, with over 32 such training being completed.

- January 2010. Application of GIS to Planning and Management of Livestock Development Services. This three-weeks-technical level training was attended by 15 officials of different divisions of the Department of Livestock Services, Ministry of Agriculture and Cooperatives.

\section{Strengthening CDG's GIS/RS Lab}

- 2011. CDG has been awarded a grant of Rs 500,000 by the Tribhuvan University's Central Office, Kirtipur for strengthening its GIS/RS laboratory. The money is being spent for buying the desktop computer sets capable of running ArcGIS software that the Department received from the ESRI, USA. The CDG has 15 ArcGIS keys, with a total cost of about Rs $4,500,000$ at the current price. 


\section{Collaborations}

CDG has successfully extended the academic agreements through signing on the Memorandum of Understanding for research and scientific exchange with the following universities ${ }^{1}$ and research centres, UNDP supported programme, and the government supported organization:

(i) Foreign Universities

- $\quad$ 2010. J. Selye University (JSU), Komárno, Hungary

- 2010. Centre for Himalayan Studies, French National Centre for Scientific Research (Centre National de la Recherche Scientifique - CNRS), Paris, France

- 2010. Alpen-Adria-University Klagenfurt, Austria

- 2011. University of Graz, Austria

- 2011. University of Arizona, USA

- 2011. Department of Land Use/Cover Change and Land Resources, Institute of Geographic Sciences and Natural Resources Research (IGSNRR), Chinese Academy of Sciences, Beijing, China

(ii) National Organizations

- 2010. Nepal Tourism Board for the partnership in research activities, particularly to support the Master's students of Geography

- 2010. Micro Enterprise Development Programme (MEDEP), Ministry of Industry, Commerce and Supply (MOICS), and United Nations Development Programme (UNDP) to support Master's students for their thesis.

\section{Seminars/Conferences}

- October-November 2011. In order to enhance knowledge of the scholars on geographic contemporary issues and problems through sharing experiences, CDG has successfully carried out an International Geographic Union (IGU) Conference on 'Geography of Governance: Dynamics for Local Development' in Kathmandu in October 2011. The conference was held in collaboration with the IGU Commission of Geography of Governance. ${ }^{2}$ A total of 52 participants comprising 19 from Czech, Israel, Japan, Poland, Slovak, Slovenia, and Norway, 3 from India, and 30 from Nepal representing not only from Geography discipline but

\footnotetext{
1 The universities for academic collaboration for research and scientific exchange, which are under process include: (i) Wake Forest University, USA, (ii) University of Zagreb, Croatia, (iii) University of Malaya, Malaysia, (iv) Nordic Centre, Uppsala University, (v) Technical University of Graz, Graz, Austria, (vi) University of Ljubljana, Slovenia, (vii) University of Primorska, Koper, Slovenia, (viii) Comenius University, Bratislava, Slovakia, and (ix) Szent István University, Gödöllö, Hungary, and (x) Australian National University, Australia.

2 The programme was inaugurated by lighting a traditional lamp - Pānas by three young girls, followed by welcome speech by Dr Ján Buèek, Chairperson of the IGU Commission on Geography of Governance and then introductory speech about the conference programme by Prof Dr Pushkar K Pradhan, Member of the Steering Committee of the IGU Commission on Geography of Governance and Convener of the IGU Conference, Kathmandu, Nepal. On the last day, speech on the concluding remark was delivered by Prof Dr Soorya L Amatya, Rector of the Tribhuvan University. Culture tour was also held for the participants to Bhaktapur city, followed by cultural programme cum dinner. Upon completion of the conference session, an excursion for the foreign participants was also carried out to the Pokhara valley and Ghale Gaun- a Home Stay Tourism Programme.
} 
also other disciplines such as economics, environmental science, rural development, and others.

- 2010. CDG's faculty members - Dr Hriday Lal Koirala attended the training programme on "Satellite Remote Sensing for Air Quality Analysis in the Himalayan Region" held at ICIMOD and likewise Mr Chhabi Lal Chidi participated in the national workshop cum training on "National Workshop on Development and Harmonization of Land Cover Classification of Nepal within the HKH Region" held at ICIMOD.

- March, 2011. On the invitation of Univ.-Prof. Dr. Hubert Lengauer, Vice-Rector of the AlpenAdria-University Klagenfurt, Austria, Prof Pradhan participated the International Exhibitioncum-Seminar on "Alps and Himalaya - yesterday, today and tomorrow" being held at Klagenfurt, Austria. Prof Dr Pradhan also attended a joint IGU Conference on marginality being held in Austria and Switzerland by the University of Graz and University of Fribourg, Switzerland.

- November 2011. Prof Narendra R Khanal attended and presented the paper "Land System vulnerability: A Case Study of Chure Hills in Nepal" in the international workshop on Global Land Project and Risk of Glacial Lake Outburst Floods in Nepal organized by the Hokkaido University, Sapporo, Japan.

\section{Talk Programmes}

To make the faculty members and students of geography aware with the contemporary geographic concepts, approaches, trend, or developments, two talk programmes by the international scholars were held at CDG, such as:

- 2011. Global Climate Change and Melting of Himalayan Glaciers by Jeffrey S. Kargel, University of Arizona, USA.

- 2010. Instant Photo Change of Nepal Himalayas by Alton Byers, Director of Research and Education, the Mountain Institute (TMI), USA.

\section{Miscellaneous}

- 2011. Subject Committee of Geography has been formed under the Chairmanship of Head of CDG - Prof Dr Pushkar K Pradhan.

- 2011. On behalf of the CDG/TU, Prof Pushkar K Pradhan chaired the kick off meeting participated by 14 organizations working in GIS/RS in Nepal that was initiated by the World Bank Office on Sharing Experiences on Mapping and GIS Initiatives and to form a network of GIS/RS organizations.

- 2010. Book launching of "Unleashing Economic Growth: Region-based Urban Development Strategy for Nepal" co-authored by Pushkar K Pradhan and published by Asian Development Bank (ADB).

- 2010. CDG - a core member of the Consortium for Land Research and Policy Dialogue, (COLARP). 


\section{Ways Forward}

In regard to academic enhancement, updating, and strengthening of the institution and its faculty members, CDG is always keen to involve in various types of academic activities. The followings are the academic activities and programmes being held in 2012 and onward.

- Inception Workshops on the joint studies -Vulnerability Assessment of Meteorological Flash Floods in Poiqu/Bhotekoshi/Sunkoshi Watershed and Climate Change Adaptation through Water Resource Management: Comparative Study between the Yellow and the Koshi River Basins are scheduled to be held in May 2012.

- An international symposium on "Changing Mountain Environments in Asia" is going to be held in Kathmandu in October 2012 by the joint effort of CDG with the Hokkaido University and Global Land Project Sapporo Nodal Office Japan.

- CDG has registered with NSPIRES as a collaborator for the joint research projects with the agencies of USA such as the Arizona University, as well as for joint publications. https://nspires.nasaprs.com/external/aboutRegistration.do

- CDG as a lead partner with the Department of Geography, University of Bergen, Norway, and other possible partners is going to apply proposal to the Collaborative Research Programme NORHED - Norwegian Programme for Capacity Building in Higher Education and Research for seeking support to the institutional and faculty academic enhancement. The proposed research would be Land use change, agricultural systems and food security in Nepal under the broad topic "Natural resource management, climate and environment."

- A collaboration work with the Indian Institute of Remote Sensing (IIRS), Indian Space Research Organization (ISRO) has begun through the visit of Dr. S. K. Saha, Dean \& Group Director of the Earth Resources \& System Studies Group, Dehradun, Uttarakhand in CDG, who also kindly delivered lecture on RS \& GIS Applications in Natural Resources Inventory \& Management in Mountain Areas - Indian Experiences.

\section{Human Resources - faculty members}

CDG consists of a team of faculty members with specialized in different fields of studies, working for academic enhancement of geographic related subjects.

- Pushkar K PRADHAN. Professor and Head. PhD (Institute of Geography \& Regional Science, Klagenfurt University, Austria), MSc (HSD, AIT Bangkok), MA (Geography, TU). Urban Studies, Urban-Rural Linkages, Regional Development Planning, Urban Informal Sector, Micro Enterprises and Livelihood, GIS/RS, Natural Resource Management, Monitoring and Evaluation and Public Policies and Development.

- Bhim P SUBEDI. Professor. PhD (University of Hawaii, USA), MA Dist. (TU). Population, Sustainable Livelihoods, Field Methods, Migration and Development.

- Padma C POUDEL. Professor. PhD (Banaras Hindu University, India), MA (TU). Tourism \& Environment, Urban Development \& Planning, Irrigation Management and Monitoring.

- Narendra R KHANAL. Professor. PhD (TU), MA (TU). Mountain Geography, Natural Resource Management, GIS, Quantitative Technique and Natural Hazards. 
- Hriday L KOIRALA. Reader. PhD (University of Guhati, India), MTech (Andhra University, India), MA (TU). RS/GIS, EIA and Urban Environment.

- Pashupati NEPAL. Reader. PhD (TU, Nepal), MA (TU). Physical Geography, Local Organization, Urban Rural Studies, Settlement Studies, Field Studies.

- Dharani K SHARMA. Reader, PhD (TU), MA (TU). Modern Geographical Thought, Political Economics, Urban Studies, and Field Studies.

- Moti L GHIMIRE. Lecturer. PhD (Japan), MTech (Andhra University, India), MA (TU). Applied Geomorphology, Mountain Environment, GIS/RS.

- Dhyanendra RAl. Lecturer. PhD on-going. MA (TU). Physical and Human Geography, Field Studies.

- Umesh K MANDAL. Reader. PhD on-going. MTech (Andhra University, India), MA (TU). Quantitative Technique, RS/GIS, Regional Planning, Agriculture Geography.

- Shobha SHRESTHA. Lecturer. PhD on-going. MSc (ITC, the Netherlands), MA Dist. (TU). Geoinformatics, Development and Planning, Service Accessibility.

- $\quad$ Kanhaiya SAPKOTA. Reader. PhD on-going. MPhil (University of Bergen, Norway), MA (TU) Human Ecology, Urban and Peri-urban Agriculture, Research Methodology and Sustainable Development.

- Puspa SHARMA. Lecturer. PhD on-going. MA (TU). Natural Hazards, Geographical Thought, Natural Resources Management, GIS/RS.

- $\quad$ Prem S ChAPAGAIN. Reader. PhD (TU), MPhil (University of Bergen, Norway), MA Dist. (TU). Human Ecology, Mountain Environment, Rural Development Planning and GIS.

- $\quad$ Chhabi L CHIDI. Lecturer. PhD in registration process. MA (TU). Human Settlement, Field Survey Desktop Cartography, and EIA

- $\quad$ Sher B GURUNG. Teaching Assistant. PhD in registration process. MA (TU). Geomorphology, Research Methodology, Geographical Thought, Practical Geography, Field Survey and RS/ GIS.

In addition, CDG has supporting administrative staff members, comprising Account Officer - Hari Amatya, administrative officer - Gyanu R Maharjan, GIS technician, Dhurb B Bogati and four other supporting staffers. 